\title{
Competing priorities: Women's microenterprises and household relationships
}

\author{
Sophia Friedson-Ridenour ${ }^{\mathrm{a}}$, Rachael S. Pierotti ${ }^{\mathrm{b}, *}$ \\ ${ }^{a}$ Department of Educational Policy Studies, University of Wisconsin-Madison, Madison, USA \\ ${ }^{\mathrm{b}}$ The World Bank, Washington DC, USA
}

\section{A R T I C L E I N F O}

\section{Article history:}

Accepted 17 April 2019

\section{Keywords:}

Gender

Ghana

Intrahousehold dynamics

Microenterprises

Savings

sub-Saharan Africa

\begin{abstract}
A B S T R A C T
Recent studies have suggested that women's business decisions are influenced by members of their household, especially their spouse, and that these intrahousehold dynamics contribute to gender gaps in entrepreneurship outcomes. This in-depth qualitative study among microentrepreneurs in urban Ghana sought to understand the connections between women's businesses and their households' management of economic resources. The findings show that women's business decisions are influenced by: 1) a desire to reinforce their partner's responsibilities as a primary provider; 2) attempts to fulfil normative expectations of meeting the daily basic-needs of the family; and 3) a need to prepare for long-term security. To reinforce their husband's responsibilities as a provider, women hid income and savings, and sometimes explicitly limited business growth. To ensure their ability to smooth household consumption and respond to emergencies, women prioritized savings over business investment. And, to plan for their long-term security, women opted for cautious business investment, instead maintaining pressure on their partner to meet current needs and investing in children and property for the future. Previous studies document gender differences in microenterprise business management. This research builds on those studies by examining how intrahousehold inequalities affect women's business decisions. The findings demonstrate the contextual importance of social relations for understanding women's business decisions. More broadly, the findings illustrate that interpersonal interactions concerning the management of economic resources are an integral part of how household members negotiate their rights and responsibilities in relation to each other.
\end{abstract}

(c) 2019 Published by Elsevier Ltd.

\section{Introduction}

Female-owned microenterprises have been promoted in development policy circles as a powerful engine of economic growth, poverty alleviation, and a pathway to the reduction of gender inequality (Agyapong, 2010; Fox and Sohnesen, 2012; Kepha et al., 2013; Muzondi, 2014). At the same time, research has documented gender gaps in microenterprise business investment and performance, which can serve to reproduce gender inequality and hinder economic growth. In several experiments that attempt to reduce capital constraints faced by microentrepreneurs, women appear less likely than men to invest available capital in their business (De Mel et al., 2009; Fafchamps et al., 2014; Berge et al., 2015). Recent research has increasingly pointed toward intrahousehold

\footnotetext{
* Corresponding author at: Africa Gender Innovation Lab (AFRGI), Office of the Chief Economist, Africa Region, The World Bank, 1818 H Street NW, Washington DC 20433, USA.

E-mail addresses: sophia@developmentpraxis.com (S. Friedson-Ridenour), rpierotti@worldbank.org (R.S. Pierotti).
}

dynamics as an important mediating factor in women's business development, potentially influencing women's business management and investment decisions (Bernhardt, Field, Pande, \& Rigol, 2017).

Building on this research, this paper investigates how women's business decisions are influenced by their relationships, particularly those between spouses. Based on an in-depth qualitative study of women microentrepreneurs in urban Ghana, we explore the intertwined nature of intrahousehold relationship and economic resource management practices, and the implications of that structure for women's business. We find that women's efforts to arrange their relationships to best meet their short and long-term needs can influence the decisions they make about their business in several ways. In particular, business decisions are influenced by: 1) a desire to maintain pressure on their partner to take responsibility for certain expenses; 2 ) attempts to fulfil normative expectations regarding daily provision of needs for the family; and 3) a need to prepare for long-term security. This paper, therefore, begins to address a gap in the development economics literature 
on how and why intrahousehold relationships are related to women's business management. The paper also adds to the relatively new literature that brings a sociological and anthropological perspective to how money is managed within urban households in low-income countries (Johnson, 2017).

The next two sections review literature on intrahousehold economic management and women entrepreneurs. These are followed by a discussion of the research methodology and the study's findings.

\section{Literature review}

\subsection{Intrahousehold resource management}

Scholars spanning the social science disciplines have recognized the complex and gendered nature of resource management within households (Guyer, 1988; Kabeer, 1994; Quisumbing, 2003; Kevane, 2012; Johnson, 2017). The unitary model of the household, which assumes that all household members are striving to maximize one budget to achieve the same goals, has proven inadequate to describe predominant household resource management practices worldwide (Doss, 1996; Quisumbing and Maluccio, 2003; Fiala and He, 2016). Studies have shown that who controls the resources within a household influences how those resources are spent (Thomas, 1990; Lundberg et al., 1997; Duflo, 2003; Duflo and Udry, 2004; Doss, 2013). Household behaviour cannot be understood as the product of one decision unit; rather, it is influenced by the preferences and actions of multiple actors. Much of the criticism of unitary models came from feminist scholars who recognized women's disadvantaged position due to men's greater control over resources, coupled with social norms that reinforce men's power as head of household (Blumberg, 1988; Dwyer and Bruce, 1988; Agarwal, 1997). If households do not operate as a single decision-making unit, combining all sources of income and allocating all resources according to a common set of investment and consumption priorities, then how do they collectively manage economic resources?

While there is important variation across contexts and between households, studies from multiple societies in sub-Saharan Africa have documented some common household resource management practices. First, husbands and wives tend to manage their income streams separately and do not pool their money (Johnson, 2017). This pattern has been documented among rural and urban Akan households in Ghana (Mikell 1997), farming households in Kenya (Johnson, 2004), entrepreneurial households in Malawi (Johnson, 2005), as well as Yoruba households in Nigeria (van Staveren and Ode bode, 2007). Relatedly, in many households, husbands and wives do not expect and do not practice transparency regarding income. Studies in southern Ghana document intrahousehold income hiding that is consequential for household consumption (Castilla 2013). Lab-in-the-field experiments in multiple countries have shown that both men and women are willing to pay a cost to retain individual control over cash by keeping money hidden (Iversen et al., 2011; Kebede et al., 2014; Jackiela and Ozier, 2015; Barr et al., 2017).

While they keep their incomes separate, men and women also tend to be responsible for different types of expenses and to spend their income differently. Previous research has recognized a social narrative that is important for how households manage money across a number of settings. The narrative emphasizes men's responsibility to provide the resources required to meet some large and essential needs of the household-often including housing, children's school fees, staple food, and medical emergencies, although these vary across space and time-and women's corre- sponding role in helping to support the household (Johnson, 2004). Women often underplay their contributions to the household so that they do not undermine this narrative (Silberschmidt, 1999). In Burkina Faso, for example, Thorsen (2002) noted that when women downplay their contributions it allows them to simultaneously show respect for their husbands and encourage continued support from them. Men benefit by retaining their status as the household's ultimate decision-maker. This financial management arrangement means that women are often relatively excluded from large asset management and ownership, but they are responsible for daily care and sustenance for the family (Guérin, 2008; Garikipati, 2008; Garikipati et al., 2017).

While acknowledging women's subordination, as well as common patterns in resource management practices, more recent scholarship has noted that intrahousehold relationships are not fixed according to a static contract, but rather are dynamic and constantly renegotiated (Jackson, 2007; Jackson, 2012; Johnson, 2017). Economic exchanges play an important role in the definition and evolution of those relationships (Zelizer, 1994, 2012). Despite their relative disadvantage, women exercise agency within ongoing bargaining over the management of household economic resources (Kandiyoti, 1988). Crucially, couples bargain not only about how to spend the money they have, but also who should be responsible for meeting a variety of household needs (Guyer, 1988). In other words, household members bargain over who should be expected to pay for each type of expense on a regular basis. Contemporary urban households in sub-Saharan Africa experience a high degree of instability in income, in addition to facing shifting needs over the life course (Collins et al., 2009). Because economic conditions are unstable, opportunities to reshape resource management practices are frequent.

Existing studies of intrahousehold resource management have provided rich descriptions of common practices and dimensions of variation (Johnson, 2017), but there has been relatively little work linking those practices with the entrepreneurial behaviours of household members. Johnson (2004) examines how women's income and expenditure flows affect their demand for financial service products. The study in western Kenya finds that women's income streams tend to be both smaller and more regular than men's and this is part of the explanation for women's greater participation in rotating savings and credit associations (ROSCAs), which require regular small contributions. Similarly, Guérin (2006) demonstrates how women's household responsibilities and access to assets affect their borrowing and lending behaviours. The study shows that women in Senegal use financial management tools to respond to their need to meet the daily demands of the household and to maintain social network connections. Other studies show that the effects of microfinance on women's empowerment and well-being depends on the distribution of income generating activities and the financial management practices of the beneficiary households (Garikipati, 2008; Akpalu et al., 2012; Ngo and Wahhaj, 2012). Finally, Fiala (2017) conducted lab-inthe field experiments in Uganda and showed that women who hid income from their husbands in the experimental game invested business loans and grants leading to positive economic outcomes, which was not the case for women who did not pay to conceal their experimental game earnings.

None of these studies specifically examines how household resource management practices affect women's entrepreneurship behaviours, which is a gap that this study begins to fill. We turn next to literature on women's entrepreneurship in sub-Saharan Africa before discussing our findings linking intrahousehold economic resource management and the investment decisions of women entrepreneurs. 


\subsection{Women entrepreneurs}

Women's entrepreneurship is an important source of livelihoods for individuals and households in much of sub-Saharan Africa. Rates of women's entrepreneurship in Africa are among the highest in the world, in part due to a lack of other opportunities for income generation (Kelley et al., 2017). Even as policy makers continue to search for ways to support the strength and growth of women's micro and small enterprises, on average, women's businesses in sub-Saharan Africa are smaller than men's and are concentrated in low productivity sectors (World Bank, 2011). Existing research confirms that women face multiple constraints to business profitability and growth (Buvinic and Furst-Nichols, 2014).

Experiments in development economics have concluded that in comparison to male entrepreneurs, female entrepreneurs tend to invest a lower share of available capital in their businesses, which contributes to gender differences in business size and profits. Recent research on the effects of distributing small grants to female micro-entrepreneurs shows limited positive impact of cash grants on microenterprise profits (De Mel et al., 2008; Fafchamps et al., 2014; Berge et al., 2015). In particular, a study in urban Ghana found that female entrepreneurs with above average initial profits converted in-kind grants into increased profits, but that comparable entrepreneurs given cash were not able to do so. On average, male entrepreneurs generated additional profits from both cash and in-kind grants (Fafchamps et al., 2014).

Economists originally explained this gender differential in investment by citing time-inconsistent preferences-the difficulty that people face in prioritizing future gains over current consumption-and pressures to share cash with others in the household or social network (Fafchamps et al., 2014). But, Bernhardt et al. (2017) recently reanalysed data from the Ghana experiment as well as two other studies that attempted to relieve capital constraints faced by microentrepreneurs. The original studies had all documented gender gaps in investment behaviours (De Mel et al., 2008; Field et al., 2013; Fafchamps et al., 2014). The reanalysis finds that when women are the sole enterprise owner within the household, capital shocks do lead to increased profits. However, when their husbands also own enterprises, women's capital is invested into their husband's business rather than their own (Bernhardt et al., 2017). Relatedly, in a study in Sri Lanka, De Mel et al. (2008) determine that women's decision-making power and level of cooperation with their spouse affects their business investment behaviour. A study in Madagascar found that marriage is associated with benefits for men's businesses but not for women's, again suggesting that intrahousehold dynamics affect women's businesses (Nordman and Vaillant, 2014). Together, these studies provide compelling evidence that intrahousehold dynamics regarding resource generation and management play a role in women's businesses. However, understanding how intrahousehold dynamics influence women's decision-making for business investment has largely remained a black box, a gap this study of microentrepreneurs starts to address. Undoubtedly, the economic realities of the women in this study are affected by the position of Ghana in the global economy, its history of structural adjustment, and its recent economic reforms (Chalfin 2010; Hutchful 2002). Those macro-level conditions, however, are beyond the scope of this study, which focuses specifically on how individual women manage their relationships and their businesses.

\section{Context and methods}

This study took place in Accra, Ghana in early 2016 and early 2017. While findings from our research have relevance to female entrepreneurs across Ghana and other locales, this research is specific to urban women microentrepreneurs in Accra. The Metropolis area has a population of about 1.6 million. Most women, at some point in their lives, are either married or living in an informal consensual union with a partner. At the same time, divorce and separation are relatively common. Some of the women we spoke with expressed concern over their husband or partner taking a second wife or a girlfriend. According to Demographic and Health Survey data from 2014, 37 percent of urban households are female-headed. In the greater Accra area, average fertility for women is 2.8 (Ghana Statistical Service et al., 2015). These demographic characteristics are important because our findings indicate that many women, for a myriad of reasons, treat marriage as a somewhat insecure institution, which impacts their long-term planning strategies, and hence their business investment behaviours.

In Ghana, women have a long history of participation in the public sphere and active engagement in economic activity (Darkwah, 2007). They own 70 percent of household enterprises, higher than the regional average in West Africa (Fox and Sohensen, 2012). In the Accra Metropolis, a slightly higher percent of men, 15 years or older, are economically active (72\%) than women (68.5\%) (Ghana Statistical Service, 2014: 34). Overall, there is wide acceptance of women working outside of the home, and often a social expectation that they will engage in income generating activities to provide help or support for the household.

This in-depth research was designed to complement a quantitative impact evaluation of a program supporting women entrepreneurs. The quantitative study tests various strategies for increasing the impact on profits of providing cash grants to women microentrepreneurs. One of the study's treatment arms offers women a commitment savings account with mobile deposit collectors and an incentive to save at least a minimum threshold to become eligible for the cash grant. The relationship between the qualitative and quantitative studies is described further below.

As summarized in Table 1, we conducted two phases of data collection, resulting in a total of 78 interviews with 49 different respondents.

\subsection{First phase of data collection}

The first phase of qualitative data was collected in January 2016. This phase of the qualitative research was completely distinct from the quantitative study-the participants were not eligible for the intervention and were not aware of the impact evaluation. It was designed to examine common household economic resource management strategies among urban women microentrepreneurs. All participants for the first phase were recruited and interviewed at their place of work. To be selected to participate in the qualitative research, respondents had to be 18 years of age or older and self-employed with no paid employees. A short set of screening questions were asked to verify the participants' eligibility prior to enrolling them in the study. Female respondents operated in the following professions: seamstress, hairdresser, beautician, trader, caterer, food vendor, shop keeper/ provisions store, and clothes seller. Men owned the following businesses: used clothes seller; shoe maker/shoe repair; painter; selling electronics; and vulcanizer. Respondents were recruited as either key informants, through snowball sampling, or by a random market walk. Respondents were primarily women (22), but a small sub-sample of men were also enlisted (8) to gather their perspective on how household economic resources are managed. Thirty initial in-depth interviews and five follow-up interviews were conducted by two Ghanaian research assistants in the local language of the respondent's choosing. In this first phase of data collection, follow-up interviews occurred only when additional information about the respondent was required for the analysis. All interviews 
Table 1

Number of people interviewed.

\begin{tabular}{|c|c|c|c|c|c|}
\hline & Interview 1 & Interview 2 & Interview 3 & Total \# of Interviews & Total \# of Individuals \\
\hline First phase: & 30 & 5 & & 35 & 30 \\
\hline \multirow[t]{2}{*}{ Second phase: } & 13 & 12 & 18 & 43 & 19 \\
\hline & & & Total & 78 & 49 \\
\hline
\end{tabular}

were audio recorded and transcribed. The research assistants were trained and supervised by the authors who read each transcript as it was produced and provided guidance for subsequent data collection.

\subsection{Second phase of data collection}

The second phase of data collection focused primarily on how women weigh business and household priorities when thinking about savings and investment options for their microenterprises. To facilitate this investigation, data collection was embedded in the six-month pilot of the commitment savings product for the quantitative study. The qualitative study participants were interviewed during and after the commitment savings period between February and June 2017. Access to administrative savings data allowed the research team to tailor interview questions around actual individual savings behaviours. This enabled discussion of specific events and decisions, rather than discussion of general practices. Participants were aware that they were part of a program designed to encourage savings and business investment, which may have inspired some exaggeration of both behaviours, and which should be considered when examining the data. This potential weakness is offset, however, by the value of capturing real economic management decisions and justifications of actual choices.

The pilot program participants served as the sampling frame for this phase of qualitative data collection. With access to information from a short survey of the program participants and the administrative savings data, we purposively selected women entrepreneurs, most of whom were married and residing with their partner, and who represented a range of average business profits and savings behaviours. We also intentionally selected some women with children under the age of five because women in that group face significant constraints on their time, financial pressure to provide, and motivation to succeed in business.

Twelve women microentrepreneurs were initially selected to participate in three in-depth interviews each. After the second set of interviews, six additional participants were added for the third interview. Having analysed the data from the first two sets of interviews, we had narrowed the scope of our inquiry and improved our ability to elicit the desired information. The additional participants allowed us to examine emerging themes in a larger sample. Altogether, this round of research included a total of 43 interviews conducted with 19 different women. All interviews were conducted by one of the research assistants who had also worked on the first round of data collection.

The research design was based on an iterative data collection process. The research assistant prepared notes summarizing each interview and the lead researchers provided weekly feedback on the notes. After each round of interviews, the lead researchers prepared follow-up questions to be addressed in subsequent meetings with the participants. Having collaborated with the lead researchers throughout the data collection, the research assistant was familiar with the goals of the research, which increased her ability to independently determine which questions to ask during interviews and what information was relevant to report in her notes. Repeated interviews with the same individuals plus ongoing data analysis throughout the research facilitated the collection of indepth data.

In addition to ongoing analysis and memo writing throughout data collection, additional systematic analysis was conducted by coding transcripts and generating case study summaries of each respondent. A code list was generated that included descriptive codes drawn from major themes that appeared in the research questions and literature (that is, capture, profits, expenditures, and so forth) as well as more analytic codes (that is, men pay big bills, women help or support, and so forth) developed through an inductive approach. Major analytic codes that emerged were discussed with the research assistant to check for general plausibility and to provide clarity.

Among the women microentrepreneurs in our sample, there was variation in how households managed money, but also striking commonalities. The findings described below illustrate how those practices matter for women's business management decisions.

\section{Reinforcing a partner's responsibilities}

First, a lack of income transparency, the division of expenditure responsibilities, and incomplete fungibility of income streams encouraged women to manage their money in ways that would continuously reassert their partner's financial responsibilities within the household. Respondents did not view existing patterns of intrahousehold resource management as fixed, but rather their stories illustrated that current arrangements in their households were the temporary outcome of an ongoing process of negotiation. This section first describes common patterns of household resource management and then demonstrates how some women strategically managed their businesses in ways that strengthened their ability to advocate for their preferences regarding the division of household responsibilities.

In our sample, women and their partners generally had uncooperative financial management arrangements. Households were similar to what Johnson (2004, 2017) calls "independent management" systems, where both the husband and wife have their own income streams that are managed separately and dedicated to different types of expenses. Income transparency between spouses is neither expected nor practiced and knowledge about a spouse's income was generally limited to knowing whether earnings were going up or down. Women tended to judge the level of their husband's income based on the amount of money he contributed to household expenses. Some women felt more supported by their husbands than others, but none of the women lived in households where spouses had complete information about each other's earnings.

Ayisha for example, reported that she does not know how much her husband makes and if she were to ask him, he would not tell her because she says "men don't like to discuss their money issues with women." At the end of the day when her husband gets home from work, he expects her to tell him how much she made that day in her business, but she says she underreports her daily earnings because her husband does not tell her about his finances, so she does not want to tell him about hers. Similarly, Bridget said that she does not know how much her husband earns and if she should ask him he would not tell her. Likewise, if her husband should ask 
her about her income she would not say. She clarified, however, that they have never actually inquired from each other about how much the other earns. In some cases, partners did have some, albeit limited, information about the other's income. Grace said that her husband told her his original salary, but he did not tell her when he got a raise. Women generally considered it inappropriate for husbands to try to control their wives' income.

Furthermore, women and men typically thought of their income as dedicated to particular types of expenses. This was supported by a strongly gendered social narrative about women and men's financial responsibilities within the household: men pay big bills and women pay for smaller daily expenses. We found that women and men alike frame women's financial contribution as "help" or "support" rather than as a primary contribution to the household itself. As discussed above, versions of this narrative have also been documented in other settings (Thorsen, 2002; Johnson, 2017). The earmarking of big payments as the responsibility of men and small payments as the responsibility of women serves a relational purpose (Zelizer, 2012), it reinforces the hierarchical structure that favours men by downplaying the significance of women's financial contributions and justifying men's position as the household's primary decision-maker, while simultaneously reinforcing men's responsibility to provide for the household.

Women's income, therefore, is generally allocated for paying expenses classified as "small things" such as soap, cooking gas, water, children's clothes, and garbage removal, as well as things classified as the responsibility of women, such as feminine hygiene products and undergarments. Several women, for example, reported that they cannot ask their husband to buy sanitary pads, panties or brassieres, and must use their own money for those types of items. In contrast, husbands are generally seen as responsible for bigger bills such as household rent, electricity, and children's school fees. Adjo, for example, explained that, "he [her husband] pays the rent and the electricity and I pay for water and garbage collection;" a common big and small bill division between husband and wife.

Aside from the need to generate income for personal or household expenses, women also indicated that operating their own business provides a form of security, control, and autonomy for themselves. Business income is valued for the independence it provides, particularly for decisions about participating in family, community, and social events. Making monetary contributions to people and events is an important part of building and maintaining familial and social networks, and hence a safety net outside of marriage. Nana, a widow who receives support in the form of remittances from her children, said that she values her income because it allows her to make decisions for herself. Notes from her interview report that, "she attends funerals, and makes donations, and pays her transport to the funeral. All these demand money and it's not always that her children will want her to attend funerals, but they can't stop her if she has her own money. But, if she depends on them [her children] for money, they can decide for her which programs to attend and which ones not to." Nana believes that attending events like funerals and making contributions is important to ensuring that people will reciprocate for her family when the time comes. Women valued the sense of independence afforded by having a source of income.

In households with independent management systems, advocating for the allocation of economic resources according to your preferences and priorities, therefore, is not a simple matter of bargaining for control over a larger portion of household income. First of all, there is not one pot of money called "household income." Income is differentiated into separate streams and money is not fully fungible. Second, given the differentiated income streams, negotiations over who should be responsible for meeting certain types of expenses can have greater ramifications than who pays for those expenses at any one point in time (Guyer, 1988). When managing their economic resources, one of the primary imperatives for the married women microentrepreneurs in our sample was ensuring continued pressure on their partner to fulfil his responsibilities to the household, and simultaneously re-asserting the nature of those responsibilities. A series of illustrations from the interviews demonstrate how women's strategies for maintaining such pressure affect their business management. The first two examples illustrate women's efforts to reassert their husband's responsibilities in the household. The second two stories show how those efforts affect women's business management decisions.

Gloria is married and has three children who are all under the age of fourteen. She says that she does not want her husband to know that she has savings because she is afraid that if he knows, he will insist that she pay for more household and family expenses. She has a strategy for helping to meet household needs without risking reduced support from her partner. When her husband asks her for money for expenses like school fees, she takes the money from her savings, but she tells her husband that the money is a loan from a friend. Because it is ostensibly a loan, her husband will feel compelled to pay her back. The interview notes say, "She explained to me that the husband will not pay her back if he knows the "loan from her friend' is for her [actually from her savings], and that he will only tell her that the child is for both of them so why should he pay her back." Gloria's strategy avoids the possibility of claims of shared responsibility.

Bridget is married and has five children between the ages of 17 years and nine months old. She recounted efforts to ensure that her husband's income was used for expenses that she viewed as his responsibility so that her income could be protected for expenses that she knows he will not cover. In this case, she hid money she could have used for hospital bills and her husband was unhappy when he found out. She explained that, "she told her husband that she knew he will not give her money in case her mother is taken ill or for any event in her family. That is why she did not use her money for the hospital." In other words, she anticipates expenses for which she cannot make a claim on his income (needs in her natal family), so she must protect her income for those needs and insist that his income be used for expenses that can be deemed his responsibility. Bridget was not questioning the importance of accessing medical care; rather, she was acting strategically to influence whose income was used to pay for that care.

Ayisha is married and has one child who is three years old and she is also pregnant. She describes the dreaded ultimate result of loosened expenditure responsibilities within the household. She explained that she hides income from her husband because she worries that he will begin to insist that she pay for more household expenses if he knows that she has money. She imagines that if her husband knows that she has money, he will ask her to pay hospital bills when their child is ill and that he will not pay her back. The interview notes explain, "[if] it is likely to continue [his claims on her income], it may collapse her business. That is why she does not disclose all that she earns to her husband." Ayisha is worried that the erosion of distinctions regarding expenditure responsibilities will lead to the diversion of capital from her business and ultimately to business failure.

In a more extreme example, Eunice, who is married and has one child who is seven, worried that visible growth in her business could be problematic for her. She sells food in the evenings in front of her house, so her husband sees the rate at which people come and notices when her business does well. Sometimes she says he accuses her of saving secretly and requesting money from him. She worries, therefore, that if she expands her business her husband may decide to stop paying their child's school fees (his responsibility), making it her "burden." As a result, she says she "wants things to be as they are." These cases illustrate that women 
are careful to maintain pressure on their partners to fulfil responsibilities to meet certain household needs. Some of their strategies for maintaining that pressure influence how they manage their business finances and affect their investment choices.

A final illustration, with a contrasting story, further clarifies the link between expenditure responsibilities and business management decisions. Patience is married and has two children, one is five years old and the other is two. She has the most cooperative household in the sample. She explains that she wants to expand her business so that she and her husband can jointly ensure the best possible education for their children. Unlike other women in the sample, she openly claims partial responsibility for the children's education and other major expenses and is motivated to grow her business to help meet those needs. In other words, Patience can claim partial financial responsibility for bigger bills because she is not concerned that changes in her financial status will shift the nature of her relationship with her husband or his contributions to the household. The interview notes explain,

I asked the respondent to tell me her purpose of her business and she told me that, she did not have the opportunity of schooling to a high level and it's her goal to help her husband to see her children through education to the highest level they can.... I asked the respondent where she will get the money [to meet her goals], and she said that it's from her business. She said that because of this she is always exploring new [business] opportunities.

While many women did end up contributing financially towards their children's education, Patience's depiction of a sense of shared responsibility for meeting large household needs stood in stark contrast with the way other study participants talked about household responsibilities. Moreover, she explicitly linked her sense of responsibility for her children's education expenses with a desire to grow her business. Patience was unusual because she was not concerned about her income growth affecting the level of support from her husband.

For many women in this sample, encouraging their partners to continually accept responsibility for important household expenses meant hiding income and savings. For some, fear of being burdened with additional expenditure responsibilities also discouraged business investment or growth. Given the lack of transparency regarding income, women may not be able to predict whether increases in their profits due to greater investment will or will not exceed the increased burden for household expenditures that may accompany business growth, especially in relatively uncooperative households. As described by Zelizer (2005, 1994), intrahousehold economic exchanges that are part of managing business and personal finances are also tools for defining and redefining relationships. In this example, women's decisions about how they manage their money is influenced by a desire to reinforce their husband's role as primary provider for the household.

\section{Prioritizing saving}

In addition to strategically managing their finances to maintain pressure on their partners, women in the study were also committed to fulfilling the responsibilities that they viewed as within their purview. As seen in other research (Dwyer and Bruce, 1988), women in this sample are generally responsible for daily provisioning and functioning of the household. This means that they provide food for home consumption, daily small allowances to the children, small household items, and medication for household members with minor illnesses, among other things. Given the structure of household resource management, many women prior- itized savings over investment of their income to fulfil these household responsibilities.

In most of the households, men gave their wife either a fixed or variable housekeeping allowance, called "chop money." Chop money is given on a daily, weekly, or monthly basis. These transfers are meant to be used to meet household needs such as buying food and paying for children's feeding at school. Husband's do not typically discuss the amount of chop money they will give their wife, and many women said that they "managed" with whatever they received from their husband. "Managing" was emphasized as a normative expectation and women valued being able to make do and meet household needs as part of their social obligation. Women assume responsibility for making sure that the daily basic needs of household members are met, using chop money and supplementing when necessary. Gloria, for example, said that household income largely came from her husband's work, he was a barber, but she said that she, "doesn't have to leave everything on the husband to do alone." She felt that if she asked her husband for money all the time her husband would not "respect" her because as a woman, even though her husband should provide for her, she should also work to be able to provide for herself. Men also indicated that they expected women to use business income to help contribute to the household and often provided initial start-up capital for their wives' businesses for that purpose. Betty, for example, reported that her husband wants her to work, "he wants me to get money so that when he does not have money I will support him with money." She placed emphasis on being able to provide help when her husband needed it.

Because women sometimes use their income to make up for shortfalls in household support from their partner, the burden placed on them is variable and unpredictable. For some women, this put them in a position that economists call "second mover," they take their husband's contribution as given and then make decisions about the allocation of their own income. Control over personal income, therefore, does not mean that they have complete discretion over how to spend. Women indicated, for example, that their husbands paid bills such as rent, electricity, and children's school fees, but slow or bad business, loss of job, illness or inability to work, or spending money on other things could shift financial responsibilities and put increased demand on the woman's income to meet household expenses and smooth consumption.

Fulfilling these financial responsibilities led some women to prioritize savings and to be cautious about business investment. Women in the study emphasized the importance of saving for unplanned expenses and emergencies. This was part of a risk management strategy. They described saving in multiple places, often with different pots of money earmarked for distinct purposes. Most of them described saving small amounts very frequently (often daily) and attempting to accumulate savings. For example, Abena stressed the importance of saving by saying, "investing all the money without saving, [without] keeping any money for emergencies, is a challenge." Notes from an interview with Ayisha captured a similar sentiment. She worried that, "if she should invest her savings into her business she may not have any money as backup in case of emergency."

Reluctance to invest was expressed by several respondents as a desire to either grow their business from profit growth alone and/ or an unwillingness to invest large lump sums. Gloria expressed a desire to be cautious about business investment: "When I asked her why she will not invest [hypothetical lottery winnings] into her business, she told me she has to do her business step-by-step so that she can track her business' progress." Bridget had a similar response: "I asked her why she didn't invest the money she had in the bank, and she said that, the money in the bank is not from her 
business so she will not invest it in her business. Also, she said she has to plan and take care of herself and her children."

There is evidence that both women's position in their household and their self-conceptions play a role in linking household resource management and these attitudes toward saving and investment. First, the structural link relates to women's status as a second mover in many households. All entrepreneurs face risk and, in this context in Ghana, high levels of uncertainty because of relatively frequent unforeseeable negative shocks (such as theft, flooding, or destruction of business premises). In households where women are responsible for ensuring that daily consumption needs are met and where contributions from their partner are sometimes unpredictable, they have additional incentives to build cash reserves. Women are often responsible for covering shortfalls in their husband's financial contributions, whether it be insufficient chop money or not paying bills. Many women talked about how they used both their profits and their inventory for household needs when their husband's money and their savings was not enough.

Several study participants described this financial arrangement. Abena reported that she and her husband do not discuss financial matters and her husband just gives her whatever amount he wants, and she makes do. Bridget reported that her husband gives chop money every day, and if it's not enough she supplements it. In another instance, Ayisha said that she saves money in a box in her room and takes money from it any time her husband's work is down and he does not have enough for housekeeping money. These women know that they will sometimes have to dip into their savings to ensure that household needs are met, and they have limited ability to predict when and how much they will need to draw from savings. When facing uncertain or irregular support from their partner, coupled with the uncertainty built into the business environment, women felt compelled to prioritize saving and were wary of risky investment. Because they are a source of informal insurance within the household, some women had incentives to limit their exposure to risk in the market.

The impact of this structure of household resource management was heightened because many women's identity and social standing was imbued with their ability to meet daily household needs and other social network obligations. They designed their personal financial management to maximize the chances that they could fulfil normative expectations, and that often meant prioritizing saving. Women in the sample described their strong desire to be able to meet the daily needs of the household, especially the needs of the children. For example, Gloria reported that even though her husband provides for the majority of household needs, she still feels compelled to save for emergencies because an inability to meet household needs, like medication when the children are sick, will cause her to feel 'disgrace.' She said that, "she must be able to save because they have three children and in case of emergency the family will not be disgraced." Another respondent expressed a similar sentiment about the need to have money on hand for emergency social obligations. Bridget explained that "as a woman, she needs to keep at least $\mathrm{GH} \leftarrow 500$ at home so that in case of emergency she can rely on that money." Like many women in the sample, she reports that she will not use the money she keeps for emergencies for her business.

Women also wanted to be able to fulfil the small daily desires of their children without having to rely on their spouse or assistance from outside the house. Gloria explained that,

As a mother she cannot ask her children to go to their father for money to buy toffees if her children should ask her. She also said that her children ask her for money to buy sachet water and that her children ask her to buy their under pants and socks for them. She said that these are some of the reasons why she needs her own business so that she can make money so that if her children ask for these things she can buy it for them.

Similarly, notes from an interview with Patience explained that, Sometimes the children will ask her for bread, or a soft drink. She has to buy it for them because if she does not, with time her children will be begging others for food and soft drinks. She said that if she does not want her children to be begging, she needs to work hard to be able to supply them with their basic needs.

Women's desire to cover the daily needs of the family are tied to larger social issues of perception and status within their communities. As Patience perceives it, having her children begging others for things would not be okay.

Liquid savings are important for meeting the small daily needs of the children, and for having money in case of shortfalls in their husband's contributions or emergencies in their household or social network. The ability to meet these needs is often expressed as women's primary reason for running a business. This positions these women's businesses as generators of petty cash and emergency savings, rather than as primary income generators. For the women who understood their businesses in this way, motivation for investment and business growth was limited. Of course, not all the women in the sample did adopt this identity. As discussed above, Patience saw herself as jointly responsible with her husband for schooling her children and was motivated to grow her business to meet that goal. Janet provides another interesting exception. She runs a salon with her adult daughter and has been running her business for twenty-four years. She identifies as a business woman, and has been saving and investing in improvements to her business, like buying new hairdryers. Although Janet is married and her husband gives her regular chop money (GH৫ 10 daily for personal use) she said that she was the one primarily responsible for paying for her children's schooling with the profits from her business. She, therefore, thinks about her business as being primary, not secondary, to meeting family needs and did not position herself as providing help or support to her husband.

In sum, then, in households where resource management practices positioned women's businesses as generators of petty cash and emergency savings, women tended to prioritize savings and to shy away from business investment. There is a structural incentive to emphasize savings because they are expected to be able to smooth household consumption and respond in cases of emergency, even to the detriment of their own business when necessary. This is compounded by normative pressure on women to ensure that the family's basic needs are met on a daily basis. Most married women do not face normative pressure to invest and grow their businesses. In contrast, men are expected to provide the major source of income for their family, which encourages business investment and growth.

\section{Long-term planning}

When examining the priorities of the women entrepreneurs in this sample, one final feature of household resource management structures emerged as important for how women manage their own business income. In particular, many of the women in the sample viewed their marriages as insecure over the long-term. Janet, for example, not only distrusted her husband with money issues, but when talking about long-term security, she bypassed any discussion of her husband and instead emphasized her own savings and not wanting to be a burden on her children. Interview notes state, "She explained to me that her savings with the bank in Ministries is towards her old age when she cannot work so that she doesn't have to depend on her children all the time." Coupled with 
women's disadvantages regarding asset ownership in marriage, marital insecurity encouraged women to dedicate business income to long-term investments independent of their husbands. For many women, their claim on their husband's present income is tenuous; their claim on his future income, savings, or assets is highly uncertain. This encourages independent long-term investment.

Rather than invest in growing their business, therefore, some women opt to maintain pressure on their partner to meet current needs, so that they can invest in long-term security. Long-term investments most often take the form of contributions toward children's education, with the hope that children will provide old-age support, and purchases of land or housing. In this context, business growth is viewed as an uncertain form of long-term security due, in part, to frequent negative shocks. Gifty, for example, had all her goods destroyed in a flood two years ago, and this experience made her wary of investing large sums of money into her business. At the same time, interview notes explain,

She does not want to invest huge sums of money into her business because she is saving to finish her building. She says she saves her money for her building project and after she finished with her building project she can invest into her business.

In other words, she prioritizes investing in her building project which will mean property ownership that can provide long-term security and a future source of income, rather than growing her business in the short-term. In studies that measure the effects of providing additional capital to business owners on their profits, Gifty's choice to spend potential business capital on a building project would look like the prioritization of short-term consumption over business investment, but, to the contrary, it is an investment in long-term security and a long-term risk management strategy.

One of the study respondents told a story that clearly illustrated the risk associated with insecure marriage. During a second interview with Comfort, unprovoked, she began the discussion by recounting how she felt betrayed by her husband because she had been contributing money from her income to him while he built a house, which she assumed would be for the family to live in. Comfort was married with three children and talked about how she had struggled, and kept taking on more and more of the economic responsibility for the children and herself, but assumed that it would pay off because soon the family would have a house of their own and she could move her shop to the new location and run her business there. They would no longer have to pay rent for the house or for her business. Recently, however, she found out that her husband had bought a car, which he had been hiding from the family, and that although the house was now finished, he refused to take the family to see it and showed no signs of moving the family into it. She felt a betrayal of trust, feeling that she had been struggling and giving her money for nothing all this time, assuming that her husband needed it and that she was contributing to her family's wellbeing.

It was instances such as this that women had either experienced themselves, or knew someone who had, that contributed to an overarching sense that marriage was not necessarily a means of ensuring long-term security. Many women, therefore, relied on and prioritized their business income for making long-term investments. Adjo, for example, explained that in the future she plans to take over her mother's business and to use the proceeds to buy a plot of land to build a house. Interview notes say that,

She will buy hers [property], her husband will also buy his [property]. There is nothing wrong with this...If her husband owns a property and she also owns one it is good. Her husband's property will not replace hers and it will not be hers.
Women like Adjo are motivated to use their business income for long-term security because they do not feel that they can rely on their husbands to provide support in the future.

In addition to owning property, especially when marriage is viewed as insecure, many women linked investments in their children's education to long-term security. Rose, for example, has three adult children and believes that because she invested in her children's education, now that they are grown, they will contribute money to help build her a house. The interview notes explain,

I asked the respondent [Rose] to tell me whether she will invest her savings in her children or in her business and she told me she will invest her savings in her children because if her business collapsed, it's her children who will take of her. She said that if anything happens to her, she will be depending on her children so she will invest in them. Though she gets everything from her business she will invest in her children's education.

The reality of insecure marriages and limited marital property rights for women encourages long-term investment in land or children rather than present-day business investments.

\section{Conclusion}

This paper begins to address a gap in our understanding of why and how women's businesses are influenced by intrahousehold dynamics. Policy makers aim to support women entrepreneurs as a means of simultaneously promoting economic growth and women's empowerment. Their efforts have been frustrated by evidence from economics that women entrepreneurs are less likely than men to translate support in the form of additional capital into improved business outcomes. At the same time, anthropological and sociological studies have documented the complexities of intrahousehold resource management practices. Some studies have shown how those practices influence women's use of financial services (for example, Johnson, 2004), but few have examined how household dynamics affect women's businesses. In response, this study among microentrepreneurs in urban Ghana sought to understand the connections between women's businesses and their households.

The analysis finds that, in trying to secure adequate resources in the present and for the future, women adjust their management strategies in ways that can be consequential for their businesses. To reinforce their husband's responsibilities as the primary provider, women hid income and savings, and sometimes explicitly limited business growth. To ensure their ability to smooth household consumption and respond in cases of emergency or unexpected expenses, women prioritized savings over investment. And, to plan for their long-term security, women opted to be cautious about business investment, instead maintaining pressure on their partner to meet current needs and investing in children and property for the future. These findings illuminate how a woman's efforts to structure her intrahousehold relationships to best meet her needs may constrain the decisions that she makes about her business.

This research shows that efforts to support women microentrepreneurs need to consider women's responsibilities within their households and attendant normative expectations, their perceptions regarding the role of their business in meeting household needs, and their priorities that compete with business growth. Women's business investment decisions are affected by the risks they face in other parts of their lives. Increasing security by improving marital property rights for women or improving social safety nets could change the calculus that currently leads some women to prioritize savings over investment. In addition, 
supporting women's savings accumulation may be an important way to increase investment. If women feel that they have adequate savings to respond to household needs and emergencies, they may feel better prepared to invest in their businesses.

Furthermore, the findings illustrate that it can be a mistake to assume that economic decision-making is an individual process. Rather, social relationships are implicated in business decisions, such as choices about business investment. Interventions that support women microentrepreneurs, therefore, should not assume that owners will make use of programmatic support to maximize business profits. Programs that relieve capital constraints, for example, will likely have differential effects depending on the role of the recipient's business in generating household economic resources and in defining intrahousehold relationships and responsibilities. Future research is needed to explore variation in household economic resource management practices and associated heterogeneity in business management practices. Resource management practices may vary by type of marriage, for example, and we could gain further understanding of the links between intrahousehold dynamics and microentrepreneurs' business decisions by examining that variation. Additional research should also examine how both wives and husbands characterize intrahousehold resource management and their livelihood strategies. Such research would provide insights into the types of intrahousehold dynamics that best support women's business growth and would help to identify opportunities to leverage business development programs to support women's short and long-term security.

\section{Conflict of interest statement}

The authors, Sophia Friedson-Ridenour and Rachael S. Pierotti, have no conflicts of interest that could inappropriately influence, or appear to influence, the research presented in this manuscript. We have no financial, personal, or other relationships, that could present actual or potential conflicts of interest.

\section{Acknowledgments}

This research was made possible through the generous financial support of several groups within the World Bank, including the Umbrella Facility for Gender Equality, Africa Gender Innovation Lab, Ghana Country Office, and the Finance, Competitiveness, and Innovation Global Practice. The research would not have been possible without the work of Cassandra Mercy Ofori, Lydia Amoah, and Papa Peter Kwame Kpodo. Thank you also to Marine Gassier, Francisco Campos, and Michelle Poulin. All errors are our own.

\section{References}

Agarwal, B. (1997). Bargaining and gender relations: Within and beyond the household. Feminist Economics, 3(1), 1-51.

Agyapong, D. (2010). Micro, small and medium enterprises' activities, income level and poverty reduction in Ghana - A synthesis of related literature. International Journal of Business Management, 5(12), 196-205.

Akpalu, W., Alnaa, E. S., \& Aglobitse, P. B. (2012). Access to microfinance and intrahousehold business decision making: Implication for efficiency of female owned enterprises in Ghana. Journal of Socio-Economics, 41, 513-518.

Barr, A., Dekker, M., Janssens, W., Kebede, B., and Kramer, B. (2017). Cooperation in polygynous households (IFPRI Discussion Paper 1625). Retrieved from SSRN website: https://ssrn.com/abstract=2942240.

Berge, L. I. O., Bjorvatn, K., \& Tungodden, B. (2015). Human and financial capital for microenterprise development: Evidence from a field and lab experiment. Management Science, 61(4), 707-722.

Bernhardt, A., Field, E., Pande, R., and Rigol, N. (2017). Household matters: revisiting the returns to capital among female microentrepreneurs (NBER Working Paper No. 23358). Cambridge, MA: National Bureau of Economic Research.

Blumberg, R. L. (1988). Income under female versus male control: Hypotheses from a theory of gender stratification and data from the Third World". Journal of Family Issues, 9(1), 51-84.
Buvinic, M., \& Furst-Nichols, R. (2014). Promoting women's economic empowerment: What works? (Policy Research Working Paper No. WPS 7087). Washington, DC: World Bank.

Castilla, Carolina (2013). Ties that bind: The kin system as a mechanism of incomehiding between spouses in rural Ghana. (UNU-Wider Working Paper No 2013/007). Hamilton, NY: UNU-WIDER.

Chalfin, B. (2010). Neoliberal frontiers: An ethnography of sovereignty in West Africa. Chicago: The University of Chicago Press.

Collins, D., Morduch, J., Rutherford, S., \& Ruthven, O. (2009). Portfolios of the poor: How the world's poor Live on $\$ 2$ a day. Princeton, NJ: Princeton University Press.

Darkwah, A. (2007). Work as duty and as joy: Understanding the role of work in the lives of Ghanaian female traders of global consumer items. In S. Harley (Ed.), Women's labor in the global economy: Speaking in multiple voices (pp. 206-220). New Brunswick, NJ: Rutgers University Press.

De Mel, S., McKenzie, D., \& Woodruff, C. (2008). Returns to capital in microenterprises: Evidence from a field experiment. The Quarterly Journal of Economics, 123(4). 1329-72.9.

De Mel, S., McKenzie, D., \& Woodruff, C. (2009). Are women more credit constrained? Experimental evidence on gender and microenterprise returns. American Economic Journal: Applied Economics, 1(3), 1-32.

Doss, C. (1996). Testing among models of intrahousehold resource allocation. World Development, 24(10), 1597-1609.

Doss, C. (2013). Intrahousehold bargaining and resource allocation in developing countries (Policy Research Working Paper No. WPS 6337). Washington, DC: World Bank.

Duflo, E. (2003). Grandmothers and granddaughters: Old-age pensions and intrahousehold allocation in South Africa. The World Bank Economic Review, 17 (1), $1-25$.

Duflo, E., \& Udry, C. (2004). Intrahousehold resource allocation in Cote d'Ivoire: Social norms, separate accounts and consumption choices (NBER Working Paper No. 10498. Cambridge, MA: National Bureau of Economic Research.

Dwyer, D., \& Bruce, J. (1988). A home divided: Women and income in the Third World. Stanford, CA: Stanford University Press.

Fafchamps, M., McKenzie, D., Quinn, S., \& Woodruff, C. (2014). Microenterprise growth and the flypaper effect: Evidence from a randomized experiment in Ghana. Journal of Development Economics, 106, 211-226.

Fiala, N., \& He, X. (2016). Unitary or noncooperative household model? Evidence from couples in Uganda. The World Bank Economic Review, 30 (Suppl.), S77-S85.

Fiala, N. (2017). Business is tough but family is worse: Household bargaining and investment in microenterprises in Uganda (Working Paper 2017-05). Storrs, CT: University of Connecticut, Department of Economics.

Field, E., Pande, R., Papp, J., \& Rigol, N. (2013). Does the classic microfinance model discourage entrepreneurship among the poor? Experimental evidence from India. American Economic Review, 103(6), 2196-2226.

Fox, L., \& Sohnesen, T. P. (2012). Household enterprises in Sub-Saharan Africa: Why they matter for growth, jobs, and livelihoods (Policy Research Working Paper No. WPS 6184). Washington DC: World Bank.

Garikipati, S. (2008). The impact of lending to women on household vulnerability and women's empowerment: Evidence from India. World Development, 36(12), 2620-2642.

Garikipati, S., Agier, I., Guérin, I., \& Szafarz, A. (2017). The cost of empowerment: Multiple sources of women's debt in rural India. The Journal of Development Studies, 53(5), 700-722.

Ghana Statistical Service (2014). 2010 population \& housing census: District analytic report, accra metropolitan. Accra, Ghana: GSS

Ghana Statistical Service, Ghana Health Service, and ICF International (2015). Ghana demographic and health survey 2014. Rockville, Maryland: GSS, GHS, and ICF International.

Guérin, I. (2006). Women and money: Lessons from Senegal. Development and Change, 37(3), 549-570.

Guérin, I. (2008). L'Argent des femmes pauvres: Entre survie quotidienne, obligations familiales et normes sociales. Revue Française de Socio-Économie, 2008/2(2), 59-78.

Guyer, J. (1988). Dynamic approaches to domestic budgeting: Cases and methods from Africa. In D. Dwyer \& J. Bruce (Eds.), A home divided: Women and income in the Third World (pp. 155-172). Stanford, CA: Stanford University Press.

Hutchful, E. (2002). Ghana's adjustment experience: The paradox of reform. Switzerland: UNRISD.

Iversen, V., Jackson, C., Kebede, B., Munro, A., \& Verschoor, A. (2011). Do spouses realise cooperative gains? Experimental evidence from rural Uganda. World Development, 39(4), 569-578.

Jackson, C. (2007). Resolving risk? Marriage and creative conjugality. Development and Change, 38(1), 107-129.

Jackson, C. (2012). Introduction: Marriage, gender relations and social change". Journal of Development Studies, 48(1), 1-9.

Jakiela, P., \& Ozier, O. (2015). Does Africa need a rotten kin theorem? Experimental evidence from village economies. The Review of Economic Studies, 83(1), 231-268.

Johnson, S. (2004). Gender norms in financial markets: Evidence from Kenya. World Development, 32(8), 1355-1374.

Johnson, S. (2005). Gender relations, empowerment and microcredit: Moving on from a lost decade. The European Journal of Development Research, 17(2), 224-248. 
Johnson, S. (2017). We don't have this is mine and this is his: Managing money and the character of conjugality in Kenya. The Journal of Development Studies, 53(5), $755-768$.

Kabeer, N. (1994). Reversed realities: Gender hierarchies in development thought. London, UK: Verso.

Kebede, B., Tarazona, M., Munro, A., \& Verschoor, A. (2014). Intra-household efficiency: An experimental study from Ethiopia. Journal of African Economics, 23 (1), 105-150.

Kelley, D. J., Baumer, B. S., Candida, B., Greene, P. G., Mahdavi, M., Majbouri, M., ... Heavlow, R. (2017). Women's Entrepreneurship 2016/2017 Report. London, United Kingdom: GERA.

Kepha, O., Mokoro, A., Nyamongo, D., \& Areba, J. (2013). Constraints facing women entrepreneurs in Kenya: A case study of micro and small enterprises in Kisii County. IOSR Journal of Humanities and Social Science, 16(6), 116-124.

Kevane, M. (2012). Gendered production and consumption in rural Africa. Proceedings of the National Academy of Sciences of the United States of America, 109(31), 12350-12355.

Lundberg, S. J., Pollak, R. K., \& Wales, T. J. (1997). Do husbands and wives pool their resources? Evidence from the United Kingdom child benefit. The Journal of Human Resources, 32(3), 463-480.

Mikell, G. (1997). Pleas for domestic relief: Akan women and family courts. In G. Mikell (Ed.), African feminism: The politics of survival in sub-Saharan Africa (pp. 96-123). Philadelphia, PA: University of Pennsylvania Press.

Muzondi, L. (2014). Women's small-medium and micro enterprises as engines for income-poverty alleviation: A renewed approach to tackling urban poverty in South Africa". Mediterranean Journal of Social Sciences, 5(23), 632-638.

Ngo, T. M., \& Wahhaj, Z. (2012). Microfinance and gender empowerment. Journal of Development Economics, 99(1), 1-12.
Nordman, C. J., \& Vaillant, J. (2014). Inputs, gender roles or sharing norms? Assessing the gender performance gap among informal entrepreneurs in Madagascar (IZA Discussion Paper No. 8046). Bonn, Germany: IZA.

Quisumbing, A. R. (Ed.). (2003). Household decisions, gender, and development: A synthesis of recent research. Washington DC: International Food Policy Research Institute.

Quisumbing, A. R., \& Maluccio, J. A. (2003). Resources at marriage and intrahousehold allocation: Evidence from Bangladesh, Ethiopia, Indonesia, and South Africa. Oxford Bulletin of Economics and Statistics, 65(3), 283-327.

Silberschmidt, Ma. (1999). Women forget that men are the masters: Gender antagonism and socio-economic change in Kisii Distrcit, Kenya. Stockholm: Nordic Africa Institute.

Thomas, D. (1990). Intra-household resource allocation: An inferential approach. The Journal of Human Resources, 25(4), 635-664.

Thorsen, D. (2002). We help our Husbands! Negotiating the household budget in rural Burkina Faso. Development and Change, 33, 129-146.

Van Staveren, I., \& Ode bode, O. (2007). Gender norms as asymmetric institutions: A case study of Yoruba Women in Nigeria. Journal of Economic Issues, 41(4) 903-925.

World Bank (2011). World development report 2012: Gender equality and development. Washington, DC: The World Bank.

Zelizer, V. A. (1994). The social meaning of money: Pin money, paychecks, poor relief and other currencies. New York: Basic Books.

Zelizer, V. A. (2005). The purchase of intimacy. Princeton, NJ: Princeton University Press.

Zelizer, V. A. (2012). How I became a relational economic sociologist and what does that mean? Politics E' Society, 40(2), 145-174. 